\title{
Factors Influencing Development of Root Rot on Ginseng Caused by Cylindrocarpon destructans
}

\author{
Mahfuzur Rahman and Zamir K. Punja
}

Department of Biological Sciences, Simon Fraser University, 8888 University Drive, Burnaby, British Columbia, V5A 1S6 Canada. Accepted for publication 5 July 2005.

\begin{abstract}
Rahman, M., and Punja, Z. K. 2005. Factors influencing development of root rot on ginseng caused by Cylindrocarpon destructans. Phytopathology 95:1381-1390.

The fungus Cylindrocarpon destructans (Zins) Scholten is the cause of root rot (disappearing root rot) in many ginseng production areas in Canada. A total of 80 isolates of $C$. destructans were recovered from diseased roots in a survey of ginseng gardens in British Columbia from 2002-2004. Among these isolates, $49 \%$ were classified as highly virulent (causing lesions on unwounded mature roots) and $51 \%$ were weakly virulent (causing lesions only on previously wounded roots). Pectinase and polyphenoloxidase enzymes were produced in vitro by $C$. destructans isolates when they were grown on pectin and phenol as a substrate, respectively. However, highly virulent isolates produced significantly $(P<$ 0.001 ) higher enzyme levels compared with weakly virulent isolates. Histopathological studies of ginseng roots inoculated with a highly virulent isolate revealed direct hyphal penetration through the epidermis, followed by intracellular hyphal growth in the cortex. Subsequent cell disintegration and accumulation of phenolic compounds was observed.
\end{abstract}

ABSTRACT
Radial growth of highly and weakly virulent isolates on potato dextrose agar was highest at 18 and $21^{\circ} \mathrm{C}$, respectively and there was no growth at $35^{\circ} \mathrm{C}$. Mycelial mass production was significantly $(P \leq 0.01)$ lower at $\mathrm{pH}$ 7.0 compared with pH 5.0. To study the effects of pH (5.0 and 7.0) and wounding on disease development, ginseng roots were grown hydroponically in Hoagland's solution. Lesions were significantly larger $(P<$ $0.001)$ at $\mathrm{pH} 5.0$ compared with $\mathrm{pH} 7.0$ and wounding enhanced disease by a highly virulent isolate at both pHs. In artificially infested soil, 2 -year-old ginseng roots were most susceptible to Cylindrocarpon root rot among all root ages tested (1 to 4 years) when evaluated using a combined scale of disease incidence and severity. Root rot severity was significantly $(P<0.002)$ enhanced by increasing the inoculum density from $3.45 \times 10^{2} \mathrm{CFU} / \mathrm{g}$ of soil to $1.86 \times 10^{3} \mathrm{CFU} / \mathrm{g}$ of soil. Disease severity was higher at $20^{\circ} \mathrm{C}$ compared with 15 and $25^{\circ} \mathrm{C}$ and at $-0.02 \mathrm{MPa}$ soil moisture compared with -0.005 and $-0.001 \mathrm{MPa}$. A significant interaction between soil moisture and temperature was observed for root rot severity.

Additional keywords: disappearing root rot, epidemiology, Panax quinquefolius, pathogenicity.
American ginseng (Panax quinquefolius L.) is a member of the family Araliaceae that is highly valued as a medicinal herb in Asian countries. Over the past 2 decades, ginseng has become an important herbal crop for growers in North America, and the industry in British Columbia, Canada has been expanding since 1982. With the expansion of ginseng cultivation, seedling, foliar, and root diseases have become more apparent $(4,15,23,25)$, of which root diseases caused by several root-infecting fungi have significantly reduced root quality and yield. The production environment for ginseng, in which thick straw mulch and shade cloth are used during the summer to simulate a forest canopy environment (24), provides conditions conducive for the survival and multiplication of fungal pathogens. Ginseng is seeded in the fall season for emergence the following spring, and the roots require 4 years of growth prior to harvest (24). This prolonged period of growth exposes the root to potential infection by different fungal pathogens. For many of these diseases, there are only limited control options available $(22,43,47)$.

Previous research has shown that the fungus Cylindrocarpon destructans (Zins) Scholten (teleomorph Nectria radicicola) is a major root rot pathogen of ginseng $(25,32,34)$. The fungus has also been reported to cause decay of woody seedlings, especially conifers, and can infect a range of other hosts $(3,36,39,41)$. Isolates of $C$. destrucatans may cause symptoms of root rot, rusty root, or both on ginseng $(10,36)$, and can be involved in ginseng

Corresponding author: Z. K. Punja; E-mail address: punja@sfu.ca

DOI: 10.1094/PHYTO-95-1381

(C) 2005 The American Phytopathological Society replant failure $(34,44)$. Replant failure is a condition in which growers cannot use the same land for two consecutive ginseng crops because of buildup of inoculum of a range of pathogens $(12,14)$. Ohh et al. (22) and Hildebrand (10) reported that $C$. destructans was one of the causal organisms leading to ginseng replant problems, although other factors may also be involved.

$C$. destructans is a slow-growing fungus, and like other soilborne pathogens, including Fusarium spp., Rhizoctonia solani, and Cylindrocladium spp., can exist as highly virulent and weakly virulent strains on ginseng and coniferous hosts $(10,16,36)$. A recent report has described molecular methods to discriminate between highly virulent ginseng-adapted isolates of $C$. destructans and weakly virulent isolates from ginseng and other hosts (36). A disorder described as rusty root has been reported to be associated with weakly virulent isolates of C. destructans (10), although reproduction of symptoms and fulfillment of Koch's postulates has not yet been achieved. Root rot and rusty root symptoms are quite distinct. Root rot typically appears first at the tip of the taproot destroying the fibrous roots and progressing toward the crown. It usually affects the outer root layers first, but the core of the root eventually disintegrates, often leaving the hollow remains of the root in the soil, and as such is known as disappearing root rot. In contrast, rusty root symptoms usually appear first near the crown of the taproot as small, raised, reddish-brown discolored areas. The affected areas are only on the root surface and never penetrate deep and eventually slough off. It is not clear whether weakly virulent $C$. destructans isolates are involved in these symptoms and there is emerging evidence that Fusarium spp. can be involved in rusty root development (30). 
There is little previous published information on the effects of abiotic factors such as $\mathrm{pH}$, temperature, and soil moisture on Cylindrocarpon root rot of ginseng (10). These factors are known to influence host-pathogen interactions in a number of other soilborne diseases such as clubroot of crucifers (9), cephalosporium stripe on wheat (21), and diseases caused by Pythium and Phytophthora spp. (35). The potential involvement of cell-walldegrading enzymes in lesion development and the mechanism of host cell invasion on ginseng roots have also not been studied. The objectives of this research were to investigate some of the factors that can influence root infection by $C$. destructans such as temperature, moisture, and $\mathrm{pH}$. In addition, we investigated the effects of wounding, root age, inoculum levels, and isolate virulence on lesion development. A preliminary report from this research has been published (31).

\section{MATERIALS AND METHODS}

Isolation of $\boldsymbol{C}$. destructans from ginseng roots. Ginseng roots with characteristic root rot symptoms due to $C$. destructans that included dark brown sunken lesions and rotting of the primary root tip and lateral roots but with no rusty colored areas (Fig. 1A), were collected from several ginseng gardens located in the interior region of British Columbia (BC) (Kamloops, Armstrong, and Lilooet), Canada from 2002-2004. Tissue sections that bordered healthy and rotted tissues from 1- to 4-year-old roots were surface-sterilized by immersion in $0.45 \% \mathrm{NaOCl}$ for $3 \mathrm{~min}$ followed by two rinses in sterile water. Tissue pieces were blotted on sterile filter paper and transferred to modified rose bengal agar (MRBA) (34) followed by incubation at $18^{\circ} \mathrm{C}$ until mycelial growth was visible. Mycelium was transferred to potato dextrose agar (PDA; BDH, Darmstadt, Germany) and pure cultures were obtained by transferring hyphal tips to fresh PDA plates. Colonies were grown at ambient room temperature $\left(21 \pm 2^{\circ} \mathrm{C}\right)$ for 14 days and stored on PDA slants at $4^{\circ} \mathrm{C}$.

Pathogenicity tests. A total of $80 \mathrm{C}$. destructans isolates obtained from diseased ginseng roots were grown on PDA for 14 days at ambient laboratory conditions $\left(21 \pm 2{ }^{\circ} \mathrm{C}\right.$ ) (Fig. 1B). Mature ginseng roots (4 years old) were dug up from ginseng gardens in Kamloops, BC and gently washed. Healthy roots were inoculated with a $0.5-\mathrm{cm}^{2}$ mycelial plug of each isolate in four replicates and incubated in a sealed plastic container layered with moist paper towels. Roots were either wounded at the point of inoculation with a fine needle (an insect mounting pin) to a depth of $1.0 \times$ $0.25 \mathrm{~mm}$ in diameter or left unwounded. Lesion development was assessed after 3 weeks, and the average lesion diameter was recorded. This experiment was conducted twice and the data averaged. The 80 isolates were grouped into weakly or highly virulent classes on the basis of their ability to cause dark sunken lesions on wounded or unwounded roots, respectively (Fig. 1C).

Analysis of isolates with PCR primers. Two PCR primers (CdU3 5'-GACGATTCGGGCCGTATCTGTG-3' and CdL1b 5'CAGCGGCGCCCACTAACAAC-3') complementary to a putative intergenic spacer (IGS) sequence (GenBank Accession No. AY037554) isolated from $C$. destructans by subtractive hybridization (20) were used for the analysis of isolates. Isolates of $C$. destructans were grown on PDA for 14 days at room temperature $\left(21 \pm 2{ }^{\circ} \mathrm{C}\right.$ ), and the mycelium and spores were scraped from the surface of colonies using a glass slide. Genomic DNA was extracted as described by Al-Samarrai and Schmid (1) and subjected to the reaction conditions described by Seifert et al. (36). PCR products $(\sim 500 \mathrm{bp})$ were separated on a $1 \%$ agarose gel and stained with ethidium bromide. An isolate from Ontario (isolate 1561) included in the study by Seifert et al. (36) was used as a positive control.

Radial growth and spore production. Six isolates of $C$. destructans, three each from a highly virulent and weakly virulent category, were grown on PDA at room temperature $\left(21 \pm 2{ }^{\circ} \mathrm{C}\right)$ to measure colony growth and spore production. Radial growth was measured after 2 weeks of incubation by taking two perpendicular measurements on each colony. After 4 weeks, spores were scraped off the colony surface after adding $15 \mathrm{ml}$ of water followed by two washings with $10 \mathrm{ml}$ of water each and counted in a hemacytometer. There were three replicate dishes of each isolate, and the experiment was conducted three times. To determine the effect of temperature on radial growth, dishes containing PDA were inoculated with a 0.5 -cm-diameter mycelial plug from a 14-day-old culture of isolates 1 (highly virulent) and 14 (weakly virulent) of $C$. destructans, and four replicate dishes were placed in incubators ranging from 5 to $35^{\circ} \mathrm{C}$ at various increments. Radial growth was measured at 3 -day intervals as above. The experiment was conducted three times, and the data from all experiments were pooled after testing the homogeneity of variance.

Since a number of highly virulent isolates of $C$. destructans did not sporulate well on PDA, preliminary tests were conducted to assess several alternative media for promotion of spore production. In these tests, potato ginseng agar $(20 \mathrm{~g}$ of ginseng root, $20 \mathrm{~g}$ of potato, boiled and filtered through cheesecloth to produce $300 \mathrm{ml}$ of aqueous extract, added to $15 \mathrm{~g}$ of agar and $700 \mathrm{ml}$ of water) resulted in significantly greater spore production than any other medium tested, with isolate 1 producing $1.2 \times 10^{8}$ spores per colony compared with $1.6 \times 10^{6}$ spores per colony on PDA. Potato ginseng agar was subsequently used for inoculum production for all assays requiring spore production.

Extracellular enzyme production by $C$. destructans. Six isolates of $C$. destructans, three each from a highly virulent and weakly virulent category, were used. Isolates 1,16 , and 17 were categorized as highly virulent on the basis of their ability to cause a sunken lesion $>1-\mathrm{cm}$ diameter on unwounded roots over a 2-week period when inoculated with a $0.5-\mathrm{cm}^{2}$ mycelial plug from a 14-day-old culture. Isolates 4,14 , and 15 were weakly virulent since they did not cause a lesion on unwounded roots but produced a lesion $>1-\mathrm{cm}$ diameter on wounded (to a depth of $1.0 \times$ $0.25 \mathrm{~mm}$ in diameter with a fine insect mounting pin) roots after 10 days. For pectinase activity assays, isolates were grown on PDA for 14 days at which time a $0.5-\mathrm{cm}^{2}$ mycelial plug was placed into $20-\mathrm{ml}$ vials containing $10 \mathrm{ml}$ of broth. The broth contained mineral salts (13) and $1 \%$ pectin (P-9135; Sigma, St. Louis, MO) adjusted to $\mathrm{pH} 5.0$. The vials were incubated at $18^{\circ} \mathrm{C}$ for 3 weeks after which time the mycelial mass was carefully removed from each vial with forceps and dried at $40^{\circ} \mathrm{C}$ for $72 \mathrm{~h}$ to obtain dry weight. Seventy-five microliters of the remaining broth was pipetted into each of three wells $(0.5-\mathrm{cm}$ diameter $)$ spaced evenly apart in $90-\times 15-\mathrm{mm}$ petri dishes containing $15 \mathrm{ml}$ of agar. The agar consisted of $0.05 \%$ polygalacturoninc acid (P9135; Sigma), $1 \mathrm{mM}$ EDTA, $100 \mathrm{mM}$ Na-acetate, and $1 \%$ agarose. The plates were incubated at $34^{\circ} \mathrm{C}$ for $10 \mathrm{~h}$ and then stained with $0.05 \%$ ruthenium red for 30 min after which time they were rinsed with water and left to dry at room temperature for $24 \mathrm{~h}$. The diameter of the clear circular zone around each well was measured in two orthogonal directions. There were three vials per isolate and one petri dish per vial. The experiment was carried out three times and the data averaged. Pectinase (one unit releases $1.0 \mu \mathrm{mol}$ of galacturonic acid per $\mathrm{h}$ at $\mathrm{pH} 4.0$ and $25^{\circ} \mathrm{C}$ ) was used to estimate the enzyme activity level in the assay described above. A standard curve was developed by using several concentrations ( 0.25 to 16 units) of known enzyme activity (7).

For polyphenoloxidase (PPO) activity assays, a buffered medium (0.05 M MES, pH 6) containing basal salts (13), $0.05 \% \mathrm{~N}$ acetyl glucosamine (Sigma), was used. After autoclaving, the broth was held at $80^{\circ} \mathrm{C}$ for 5 min with constant stirring while phenol (Anachemia, Montreal, QC, Canada) substrate $(0.01 \%$, [w/v]) was added. Flasks were inoculated with a $0.5-\mathrm{cm}^{2}$ mycelial plug of $C$. destructans from a 14-day-old culture and placed on a shaker for 2 weeks after which time the content of each flask was filtered through cheesecloth to remove the mycelium, and the 

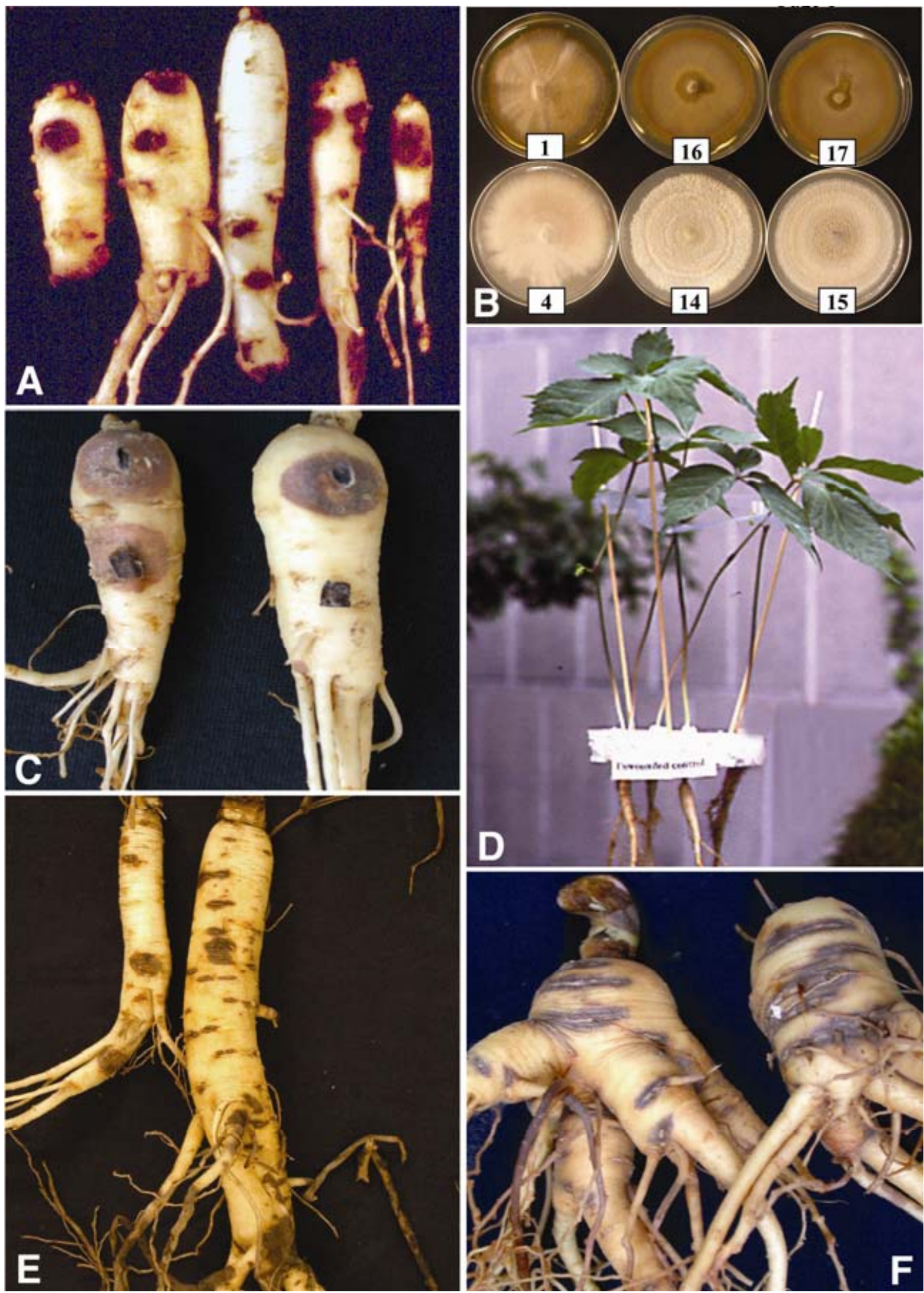

Fig. 1. Growth and development of Cylindrocarpon destructans on ginseng roots. A, Lesions on roots resulting from natural infection. B, Two-week-old colonies of highly virulent (top row) and weakly virulent (bottom row) isolates of $C$. destructans growing on potato dextrose agar. C, Lesion development by highly (left) and weakly (right) virulent isolates on 3-year-old roots 2 weeks after inoculation. A wound $(1.0 \times 0.25 \mathrm{~mm}$ in diameter) was created with a sharp insect mounting pin on the upper inoculation site while the lower inoculation site was unwounded. D, Hydroponically grown 2-year-old ginseng roots used to study infection behavior. E, Lesions on ginseng roots resulting from soil infestation with oat grain inoculum. F, Lesions developing mainly at the junctions of primary and lateral roots following mycelial spray inoculation. 
filtrate was kept on ice to use as a PPO source for each isolate. Dihydroxyphenylalanine (DOPA) solution (5 ppm) was placed in a cuvette $(900 \mu \mathrm{l})$ followed by adding $100 \mu \mathrm{l}$ of filtrate to record the increases in absorbance for $1 \mathrm{~min}$ at $280 \mathrm{~nm}$ in a Thermo Spectronic Helios UV visible spectrophotometer (Thermo Electron Corp., Cambridge, UK). One unit of the enzyme can transform DOPA into DOPA chrome by increasing 0.001 absorbance per min at $280 \mathrm{~nm}$ (8). Four replicate flasks were used for each isolate and the experiment was conducted three times.

Effect of $\mathbf{p H}$ on mycelial mass production. Citrate and phosphate buffer solutions $(0.01 \mathrm{M})$ containing citric acid/Na-citrate and $\mathrm{Na}_{2} \mathrm{HPO}_{4} / \mathrm{NaH}_{2} \mathrm{PO}_{4}$ respectively, were made to achieve pHs of 3.0, 5.0, and 7.0. Buffer solutions $(100 \mathrm{ml})$ were poured in a $250-\mathrm{ml}$ flask and the required amount of potato dextrose broth was added followed by autoclaving at $121^{\circ} \mathrm{C}$ for $15 \mathrm{~min}$. The $\mathrm{pH}$ of the cooled broth was measured and readjusted with $1 \mathrm{~N} \mathrm{HCl}$ or $\mathrm{NaOH}$ if it had changed during autoclaving. Flasks were inoculated with a $0.5-\mathrm{cm}^{2}$ mycelial plug from a 14-day old culture of isolate 1 of $C$. destructans and incubated on a rotary shaker for 2 weeks after which time the mycelial mass from each flask was filtered, dried at $40^{\circ} \mathrm{C}$ for $72 \mathrm{~h}$, and weighed. There were four replicate flasks at each $\mathrm{pH}$ and the experiment was conducted three times.

Effect of pH and wounding on root rot. A hydroponic method for maintaining ginseng roots was developed to determine the effect of $\mathrm{pH}$ on disease development and to visualize lesion expansion after wounding. Two-year-old ginseng plants were carefully dug up from a ginseng garden in Kamloops, BC. Plants with surrounding rhizosphere soil were transplanted into $15-\mathrm{cm}$ pots that were covered with polyethylene bags and brought to the laboratory within $24 \mathrm{~h}$. The roots were gently washed, and healthy roots without blemishes were inserted through pre-cut holes in a styrofoam block and suspended in a container of Hoagland's solution (Fig. 1D). Hoagland's solution (HS) was modified by adding $1 \mathrm{~N} \mathrm{HCl}$ or $\mathrm{NaOH}$ to adjust the $\mathrm{pH}$ to 5.0 or 7.0 . The $\mathrm{pH}$ was monitored daily and adjusted as needed. Wounds were made on roots by piercing them 8 to 10 times with a fine needle (an insect mounting pin) to a depth of $1.0 \times 0.25 \mathrm{~mm}$ in diameter prior to inoculation. Inoculations were conducted by adding the required amount of spore suspension from isolate 1 (produced on potato ginseng agar) to $900 \mathrm{ml}$ of HS to achieve $5 \times 10^{5}$ spores per $\mathrm{ml}$ in each container (Phytacon; Sigma Chemical Co.). Wounded and unwounded roots were randomly assigned to each of three replicate containers (each container had six roots) at each $\mathrm{pH}$ (5.0 and 7.0). One container of six roots was kept as an uninoculated control. The solution was aerated through a direct airflow line on a lab bench. Plants were incubated under low intensity light $\left(40 \mu \mathrm{mol}^{-1} \mathrm{~m}^{-2}\right)$. Roots were rated for disease incidence and severity at 3-day intervals on a continuous scale of 1 to 6 in which $1=$ no visible lesions, 2 = brown lesions up to $0.9 \mathrm{~mm}$ in diameter, $3=$ dark brown lesions of 1 to $4.0 \mathrm{~mm}, 4=$ black lesions of 4 to $7.0 \mathrm{~mm}, 5$ = black lesions $>7.0 \mathrm{~mm}$, coalesced with each other, and $6=$ fully rotten roots. A disease severity index (DSI) was then calculated using the following formula:

$$
\mathrm{DSI}=\frac{\left(X_{1} \times 1\right)+\left(X_{2} \times 2\right)+\left(X_{3} \times 3\right)+\left(X_{4} \times 4\right)+\left(X_{5} \times 5\right)+\left(X_{6} \times 6\right)}{\left(X_{1}+X_{2}+X_{3}+X_{4}+X_{5}+X_{6}\right)}
$$

in which $X_{1}, X_{2}, X_{3}, X_{4}, X_{5}$, and $X_{6}$ are the numbers of plants with rotting severity values of $1,2,3,4,5$, and 6 , respectively. Each treatment had nine replicate roots and the experiment was conducted three times. Data from disease severity in all three experiments were pooled together after testing the homogeneity of variance $(P \leq 0.05)$. Control roots did not develop any disease symptoms and hence were dropped from the analysis.

Histopathological study. Two-year-old ginseng roots were carefully dug up from a ginseng garden, the adhering soil was gently shaken off, and the roots were thoroughly washed under running tap water and examined with a stereomicroscope to select undamaged (without mechanical or biological injury) roots for this study. Roots were inoculated with $0.5-\mathrm{cm}^{2}$ mycelial plugs (three on each root) of a highly virulent isolate (isolate 1) and incubated in a sealed plastic container layered with moist paper towel for 2 weeks. Tissue samples $\left(0.5 \times 0.2 \mathrm{~cm}^{2}\right)$ from around developing lesions were cut with a scalpel and fixed in formalinacetic acid-alcohol (FAA) for $72 \mathrm{~h}$ followed by a transfer to $70 \%$ ethanol. Samples were dehydrated through an ethanol series (70, 85,95 , and $100 \%, 2 \mathrm{~h}$ each). The samples were preinfiltrated with a $100 \%$ ethanol - 2-hydroxyethylmethacrylate mixture (Technovit 7100; Marivac Ltd., Halifax, NS, Canada) (1:1 [v/v]) for $2 \mathrm{~h}$. Samples were infiltrated in Technovit $(100 \mathrm{ml}$ of Technovit 7100 and $1 \mathrm{~g}$ of hardener 1 ) for $24 \mathrm{~h}$ at $4{ }^{\circ} \mathrm{C}$ and embedded in Technovit 7100 according to the manufacturer's instructions. Cross sections (4- $\mu$ m thick) were cut through lesions with an LKB pyramitome, (Diversified Equipment Co., Lorton, VA) stained with an aqueous solution of Toluidine blue $\mathrm{O}(0.05 \%)$ for $30 \mathrm{~s}$ followed by rinsing in distilled water for $30 \mathrm{~s}$. The sections were sealed under cover slips using permount and examined with a light microscope at $\times 100$ or $\times 400$ magnification.

Effect of root age on disease severity. Inoculum of $C$. destructans was prepared by inoculating moistened autoclaved oat grains (from a local store, $1,200 \mathrm{~cm}^{3}$ in a 2-liter flask) with mycelial plugs from PDA colonies and incubating for 3 weeks at room temperature $\left(21 \pm 2^{\circ} \mathrm{C}\right)$ until the oat grains were fully colonized by mycelium. Field soil for this and subsequent experiments was collected from a ginseng garden in Kamloops, BC. The soil was a Brown Chernozemic silt-loam with $3.4 \%$ organic matter and the following nutrient levels: $\mathrm{NO}_{3}$ (21 ppm), $\mathrm{P}$ (98 ppm), K (674 ppm), $\mathrm{Ca}(7245 \mathrm{ppm}), \mathrm{Mg}$ (934 ppm), and S (73 ppm). Pots were filled with inoculum-infested soil $(5 \%[\mathrm{v} / \mathrm{v}])$, whereas control pots received uninoculated oat grains $(5 \%[\mathrm{v} / \mathrm{v}])$. Ginseng plants were carefully dug up from 1- to 4-year old ginseng gardens. The adhering soil was gently shaken off, and the roots were transplanted into inoculum-infested soil as well as in control pots (two plants in each pot). Four pots in each age group were arranged on a bench in a completely randomized design. Plants were covered with polyethylene bags to minimize water loss because of transpiration during the first 10 days after transplanting and then the bags were removed. Individual roots were evaluated for disease incidence and rot severity after 30 days of incubation at ambient room temperature $\left(21 \pm 2^{\circ} \mathrm{C}\right)$ and low light intensity $\left(40 \mu \mathrm{mol}^{-1} \mathrm{~m}^{-2}\right)$ on a 1 to 6 scale as described above. The experiment was carried out three times in the same growing season using roots from fieldgrown plants of the same ages (1 to 4 years old).

Effect of soil moisture and temperature on Cylindrocarpon root rot. Field soil was air dried to constant weight at 20 to $23^{\circ} \mathrm{C}$ (5.6\% moisture on an oven dry basis) and autoclaved twice in a dry cycle for $30 \mathrm{~min}$ at $121^{\circ} \mathrm{C}$ and $15 \mathrm{psi}$ on two consecutive days. The required amount of sterile water was added and the soil water content was adjusted to create a matric potential of -0.02 , -0.005 , and $-0.001 \mathrm{MPa}$ (ranging from near field capacity to near saturation) based on the soil moisture release curve developed for this soil type. After adding water, the soil was left overnight in a sealed polyethylene bag for uniform moisture distribution. To prepare the soil moisture release curve, air-dried soil was allowed to be saturated at $0 \mathrm{MPa}$ in a Buchner funnel. Soil water content was measured at different pressures applied through the funnel ranging from 0 to $-0.03 \mathrm{MPa}$. Colonized oat inoculum was mixed with the soil $(5 \%)$ at all three moisture levels, while controls received uncolonized oat grains. The soil samples were dispensed into containers (Sigma plant cell culture pots, Phytacon; Sigma) and covered with polyethylene bags to prevent moisture loss. Two-year-old ginseng roots from a garden in Kamloops were carefully uprooted, brought to the lab, examined for blemishes, and only healthy roots were transplanted into inoculum-infested soil as well as in control pots. Three replicate pots at each mois- 
ture level were placed in growth chambers set at 15,20 , or $25^{\circ} \mathrm{C}$. Water was added to each pot at 3-day intervals to maintain the moisture level throughout the experimental period. The required amount of water was determined by subtracting the actual pot weight from the initial pot weight, assuming the weight loss was due to water loss. After 30 days, the roots were evaluated for disease development as described previously. This experiment was conducted two times using roots and soil from the same garden. The experiment was laid out in a factorial design with soil moisture being factor one and soil temperature as factor two. The soil moisture levels $(-0.02,-0.005$, and $-0.001 \mathrm{MPa})$ were randomized in each of three replicate blocks in each of three temperaturecontrolled growth chambers. Data were analyzed using Statistical Analysis System (version 8.0; SAS Institute Inc., Cary, NC). Data from experimental repetitions were pooled together after testing the homogeneity of variance $(P \leq 0.05)$. Data were analyzed for the effect of individual factors as well as their interactions. Data for the means of treatments were compared by Fisher's protected LSD at the $5 \%$ level.

Effect of inoculum concentration and wounding on disease. Colonized oat grains were mixed with field soil at 1,5 , and $10 \%$ $(\mathrm{v} / \mathrm{v})$ to achieve initial inoculum levels of $3.45 \times 10^{2}, 1.86 \times 10^{3}$, and $3.55 \times 10^{3} \mathrm{CFU} / \mathrm{g}$ of dry soil, respectively. The inoculum concentration (CFU/g dry soil) for each level was estimated by suspending 1,5 , and $10 \mathrm{ml}$ of colonized oat grains separately in sterile water followed by gentle shaking with a glass rod for $30 \mathrm{~s}$ and appropriate dilution plating on PDA in four replicates. Colonies were counted after 3 days of incubation at ambient room temperature $\left(21 \pm 2{ }^{\circ} \mathrm{C}\right)$ and expressed as CFU per $\mathrm{g}$ of dry soil. Two-year-old ginseng plants were carefully uprooted from a ginseng garden in Kamloops, examined for blemishes, and healthy roots transplanted into infested soil as well as in control pots that received uninoculated oat grains. For each inoculum level, three replicate pots (each containing two roots) received unwounded roots and three pots received wounded roots. Wounds were created by piercing them randomly 10 times with a fine needle to a depth of $1.0-\times 0.25-\mathrm{mm}$ diameter prior to potting. The pots were covered with polyethylene bags to minimize water loss from the plants for the first 10 days after transplanting, and the soil moisture level was maintained near field capacity. Roots were evaluated individually for disease incidence and severity after 30 days on a 1 to 6 scale followed by calculating a disease severity index as described previously. This experiment was conducted three times. The experiment was laid out in a factorial design, with inoculum level being factor one and root condition (wounded or unwounded) as factor two. Wounded and unwounded roots were completely randomized in each of three replicate pots at three inoculum levels $\left(3.45 \times 10^{2}, 1.86 \times 10^{3}\right.$, and $3.55 \times 10^{3} \mathrm{CFU} / \mathrm{g}$ of dry soil). Data were analyzed using Statistical Analysis System (version 8.0; SAS Institute Inc.). Data were subjected to analysis of variance (ANOVA) and pooled together after testing the homogeneity of variance $(P \leq 0.05)$. Means of the treatments were compared by Fisher's protected LSD at the 5\% level.

\section{RESULTS}

Isolation of $C$. destructans from ginseng roots and pathogenicity trial. Despite the use of a semiselective medium, modified rose bengal agar, the recovery of $C$. destructans from root lesions was low. For all roots ( 1 to 4 years old), the average recovery of isolates from lesions was $55 \%$. A higher proportion of isolates $(65 \%)$ was obtained from 1- and 2-year-old roots followed by 3 - and 4-year old roots (35\%). The low recovery of $C$. destructans was in part due to the presence of Fusarium spp. in most lesions, which grew faster in relation to Cylindrocarpon spp. Among the 80 isolates recovered, $51 \%$ were weakly virulent and the remaining $49 \%$ were highly virulent because they could produce lesions on unwounded roots (Fig. 1C). Colonies of highly and weakly virulent isolates displayed markedly different color and mycelial compactness after 2 weeks of growth on PDA. Highly virulent isolates became dark to rust brown with a velvety colony surface, whereas weakly virulent colonies were beige to light brown with cottony aerial mycelium (Fig. 1B).

Analysis of isolates with PCR primers. The 80 isolates included in this study were tested using PCR primers (CdU3 5'GACGATTCGGGCCGTATCTGTG-3' and CdL1b 5'-CAGCGGCGCCCACTAACAAC-3'). PCR amplicons were obtained from almost all of the highly virulent isolates (categorized on the basis of root inoculation test) except seven of them. None of the weakly virulent isolates showed any amplification product. Amplicons from seven highly virulent isolates, including a positive control, are shown in Fig. 2. The control highly virulent isolate that was previously used by Seifert et al. (36) and most highly virulent isolates from this study produced the expected band of $\sim 500 \mathrm{bp}$ in size.

Radial growth and spore production. Spore production on PDA by three highly virulent isolates $(1,16$, and 17$)$ was $1.6 \times$ $10^{6}, 5 \times 10^{5}$, and $2 \times 10^{6}$ spores per colony, while spore production was $9.6 \times 10^{9}, 7.2 \times 10^{8}$, and $6.7 \times 10^{8}$ for three weakly virulent isolates $(4,14$, and 15), respectively. Exposure of $C$. destructans to different temperature regimens indicated that $18^{\circ} \mathrm{C}$ was the optimal temperature for mycelial growth of highly virulent isolate 1 (Fig. 3A), and $21^{\circ} \mathrm{C}$ was optimal for isolate 14 belonging to the weakly virulent category (Fig. 3B). Both isolates showed minimal growth at temperatures as low as $5^{\circ} \mathrm{C}$, although growth of isolate 1 was lower compared with isolate 14 . No growth was observed at $35^{\circ} \mathrm{C}$ for any of the isolates.

Effect of $\mathbf{p H}$ and wounding on root rot. Lesions appeared on wounded roots maintained in Hoagland's solution at $\mathrm{pH} 5.0$ and 7.0 as early as 5 days after inoculation compared with 11 and 14 days for unwounded roots at the same $\mathrm{pH}$ (Fig. 4). Although initial lesions appeared at almost the same time on wounded roots, irrespective of $\mathrm{pH}$, lesion expansion was much slower at $\mathrm{pH}$ 7.0 compared with $\mathrm{pH}$ 5.0, which contributed to significantly lower DSI at pH 7.0 (Fig. 4). A similar trend of the effect of $\mathrm{pH}$ was observed on unwounded roots despite the much lower DSI compared with wounded roots (Fig. 5). Although the highly virulent isolate used in this experiment was capable of producing lesions on unwounded roots, wounding enhanced disease severity for this isolate.

Effect of pH on mycelial mass production. Mycelial mass production in buffered potato dextrose broth was significantly higher $(P<0.001)$ at $\mathrm{pH} 5.0$ than at $\mathrm{pH} 3.0$ or 7.0 . The stimulatory effect of $\mathrm{pH}$ on mycelial mass production was in the order of $5.0>3.0>7.0$ (Fig. 6).

Extracellular enzyme production by $\boldsymbol{C}$. destructans. Of three weakly virulent isolates, two did not produce any detectable pecti-

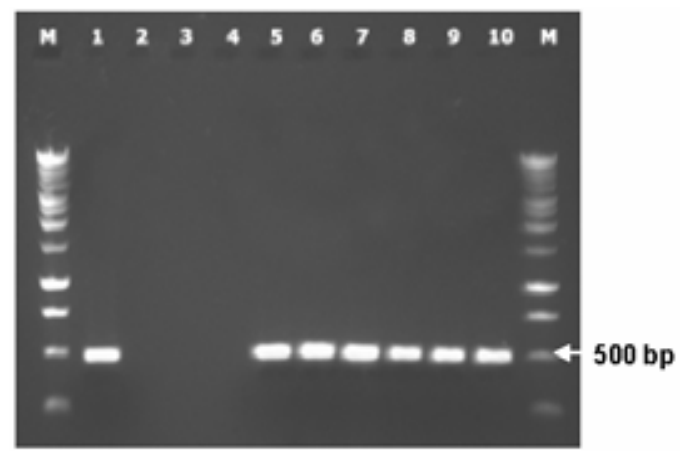

Fig. 2. Polymerase chain reaction amplification products from DNA extracted from Cylindrocarpon destructans showing bands ( 500 bp) on agarose gel. $\mathrm{M}=1-\mathrm{kb}$ ladder; lane 1 = positive control; lane 2 = negative control (water only); lanes 3 and $4=$ weakly virulent isolate 14 and 15; lanes 5 to $9=$ highly virulent isolates. 
nase and one produced a significantly lower amount (0.48 units per mg of dry mycelial weight) compared with highly virulent isolates. All three highly virulent isolates produced pectinase levels ranging from 2.63 units in isolate 1 to 1.38 units for isolates 16 and 17. The polyphenoloxidase activity level was also markedly different between the two groups of isolates. Consistent with the levels of pectinase production, highest PPO was produced by isolate 1 ( 72 units) followed by 56 and 55 units for isolates 16 and 17 , respectively. PPO production by three isolates in the weakly virulent category was 36,20 , and 35 , respectively, for isolates 4 , 14 , and 15 .

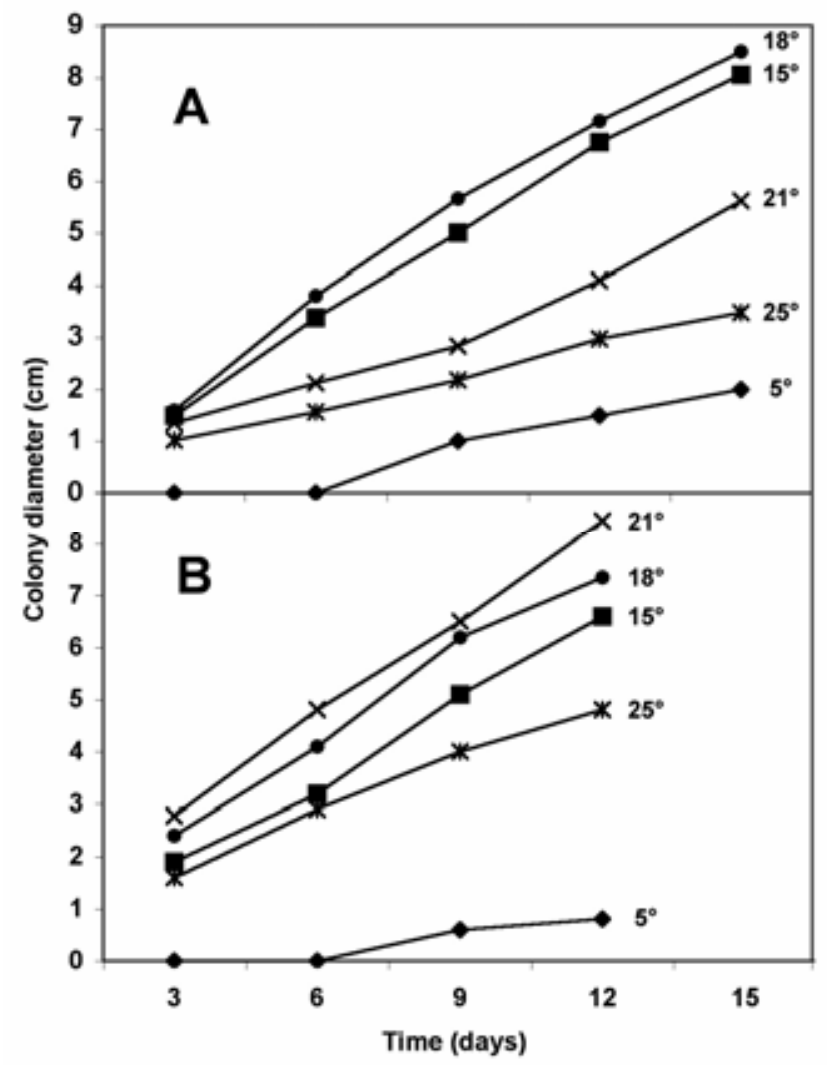

Fig. 3. Effect of temperature $\left({ }^{\circ} \mathrm{C}\right)$ on radial growth of Cylindrocarpon destructans on potato dextrose agar. A, Isolate 1 (highly virulent). B, Isolate 14 (weakly virulent).

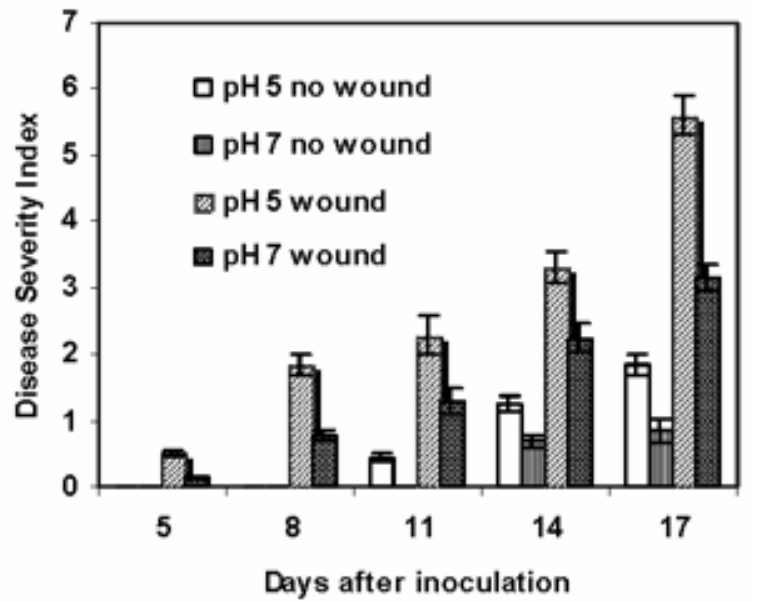

Fig. 4. Effect of $\mathrm{pH}$ and wounding on disease severity index due to Cylindrocarpon destructans on hydroponically maintained roots. Vertical bars represent the standard errors of means from three experiments $(n=27)$.
Histopathological study. Direct penetration of the epidermis by $C$. destructans hyphae was observed (Fig. 7A). Hyphal growth from the point of infection occurred mainly intracellularly and extended down through 7 to 8 cell layers within 2 weeks after inoculation (Fig. 7B). Degradation of cell walls resulted from growth of hyphae through cells (Fig. 7C). Mycelial growth inside the cells occupied entire cortical cells before extending through neighboring cells (Fig. 7C and D). Accumulation of phenolic compounds was evident by a blue-green staining characteristic of Toluidine blue (27).

Effect of root age on root rot severity. Two-year-old roots showed the highest disease severity index on the basis of infection frequency (disease incidence) and root rot severity (Table 1). Oneyear-old roots had a low infection frequency (percentage of infected roots from all first year roots included in the experiment) but some of the infected roots rotted more rapidly than 2-year-old roots as evidenced by almost total disappearance (disappearing root rot). All of the 3-and 4-year-old roots had high numbers of small shallow penetrating lesions on the root surface, which resulted in lower mortality of the plants over the course of the experiment compared with 2-year-old roots (Fig. 1E).
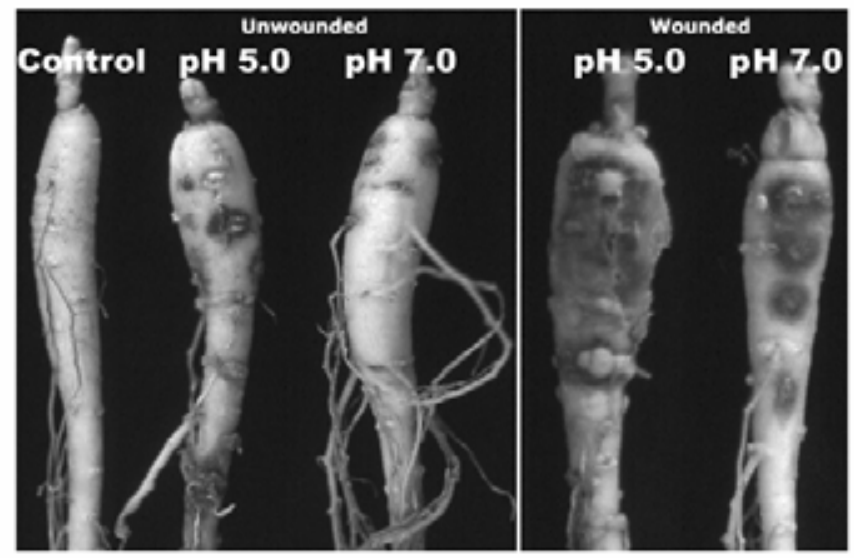

Fig. 5. Effect of $\mathrm{pH}$ and wounding on root rot development due to Cylindrocarpon destructans. A, Rot lesions on unwounded 2-year-old roots (at $\mathrm{pH} 5.0$ and 7.0) in relation to control (no inoculum). B, Lesions on wounded 2-yearold roots (at pH 5.0 and 7.0).

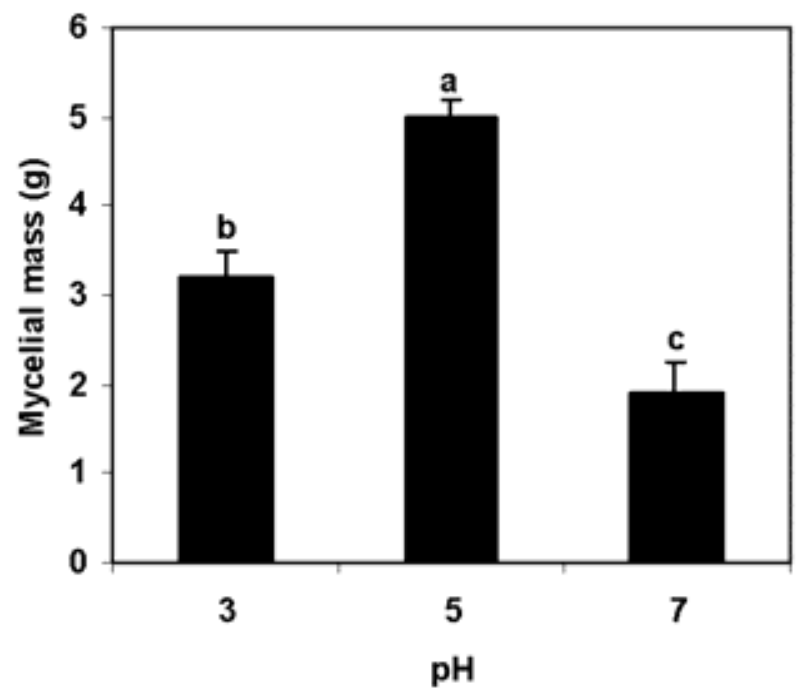

Fig. 6. Effect of $\mathrm{pH}$ on mycelial mass production by Cylindrocarpon destructans. Bars followed by different letters are significantly different from each other according to Fisher's protected LSD test $(P \leq 0.05)$. Vertical bars on the top represent the standard errors of means from three experiments each having four replicate flasks $(n=12)$. 
Effect of soil moisture and temperature on root rot. Soil temperature significantly influenced root rot severity. Highest infection and number of lesions were obtained at $20^{\circ} \mathrm{C}$ at $-0.02 \mathrm{MPa}$ soil moisture content (near field capacity). Although the soil temperature $\times$ moisture interaction was significant, individual effects from soil moisture were nonsignificant (Table 2). At all temperatures, a similar effect of soil moisture on disease was obtained with the ranking as $-0.02>-0.005>-0.001 \mathrm{MPa}$ (Fig. 8).

Effect of inoculum concentration and wounding on disease. Root rot severity was significantly influenced by inoculum concentration in the soil. Disease severity was greater with $1.86 \times 10^{3}$ compared with $3.45 \times 10^{2} \mathrm{CFU} / \mathrm{g}$ of dry soil (obtained by incorporating 1 and $5 \%(\mathrm{v} / \mathrm{v})$ colonized oatgrains in soil). However, inoculum concentration above a level of $1.86 \times 10^{3} \mathrm{CFU} / \mathrm{g}$ of dry soil (colonized oatgrains incorporated at $5 \%$ of soil volume) did not further enhance disease severity. Wounded roots showed a significantly higher rotting severity compared with unwounded roots at all inoculum levels tested (Fig. 9).

\section{DISCUSSION}

C. destructans is a recurrent problem in ginseng-growing regions worldwide causing the disease disappearing root rot $(10,44)$. The additional proposed role of the pathogen in rusty root symptoms (10) and replant failure (22) makes this fungus one of the most important pathogens of ginseng. No chemicals are currently available to control this pathogen. Zeizold et al. (45)

evaluated the toxicity of a range of fungicides against mycelial growth of $C$. destructans in vitro, as well as on disappearing root rot of ginseng (47), and also tested the efficacy as seed treatments (46). The fungicides showed very limited potential to control this pathogen in vitro or in vivo.

TABLE 1. Effect of ginseng root age on Cylindrocarpon root rot severityz

\begin{tabular}{lcccc}
\hline $\begin{array}{l}\text { Root age } \\
\text { (years) }\end{array}$ & $\begin{array}{c}\text { Highest rotting } \\
\text { severity } \\
\text { observed }\end{array}$ & $\begin{array}{c}\text { Disease } \\
\text { incidence } \\
(\%)\end{array}$ & $\begin{array}{c}\text { Plant survival } \\
\text { at 30 days after } \\
\text { inoculation }(\%)\end{array}$ & $\begin{array}{c}\text { Disease } \\
\text { severity } \\
\text { index }\end{array}$ \\
\hline 1 & $6.0 \mathrm{a}$ & $50.00 \mathrm{c}$ & $50.00 \mathrm{a}$ & $2.75 \mathrm{c}$ \\
2 & $5.0 \mathrm{~b}$ & $83.33 \mathrm{~b}$ & $8.33 \mathrm{~d}$ & $4.11 \mathrm{a}$ \\
3 & $3.9 \mathrm{c}$ & $100.00 \mathrm{a}$ & $25.00 \mathrm{c}$ & $3.75 \mathrm{ab}$ \\
4 & $3.4 \mathrm{c}$ & $100.00 \mathrm{a}$ & $41.66 \mathrm{~b}$ & $3.00 \mathrm{bc}$ \\
\hline
\end{tabular}

${ }^{\mathrm{z}}$ Data are the means of four replicates. Means followed by a different letter in a column are significantly different according to Fisher's protected LSD test $(P \leq 0.05)$.

TABLE 2. Interaction between soil temperature and moisture on Cylindrocarpon root rot severity

\begin{tabular}{lcrrrr}
\hline & \multicolumn{5}{c}{ Type III tests } \\
\cline { 2 - 6 } Source & df & Sum of & Mean \\
squares & square & $F$ stat & $\operatorname{Pr}>F$ \\
\hline Temperature & 1 & 19.48 & 19.48 & 19.48 & 0.002 \\
Moisture & 1 & 1.83 & 1.83 & 1.83 & 0.1886 \\
Temperature*moisture & 1 & 6.85 & 6.85 & 6.85 & 0.0151 \\
\hline
\end{tabular}
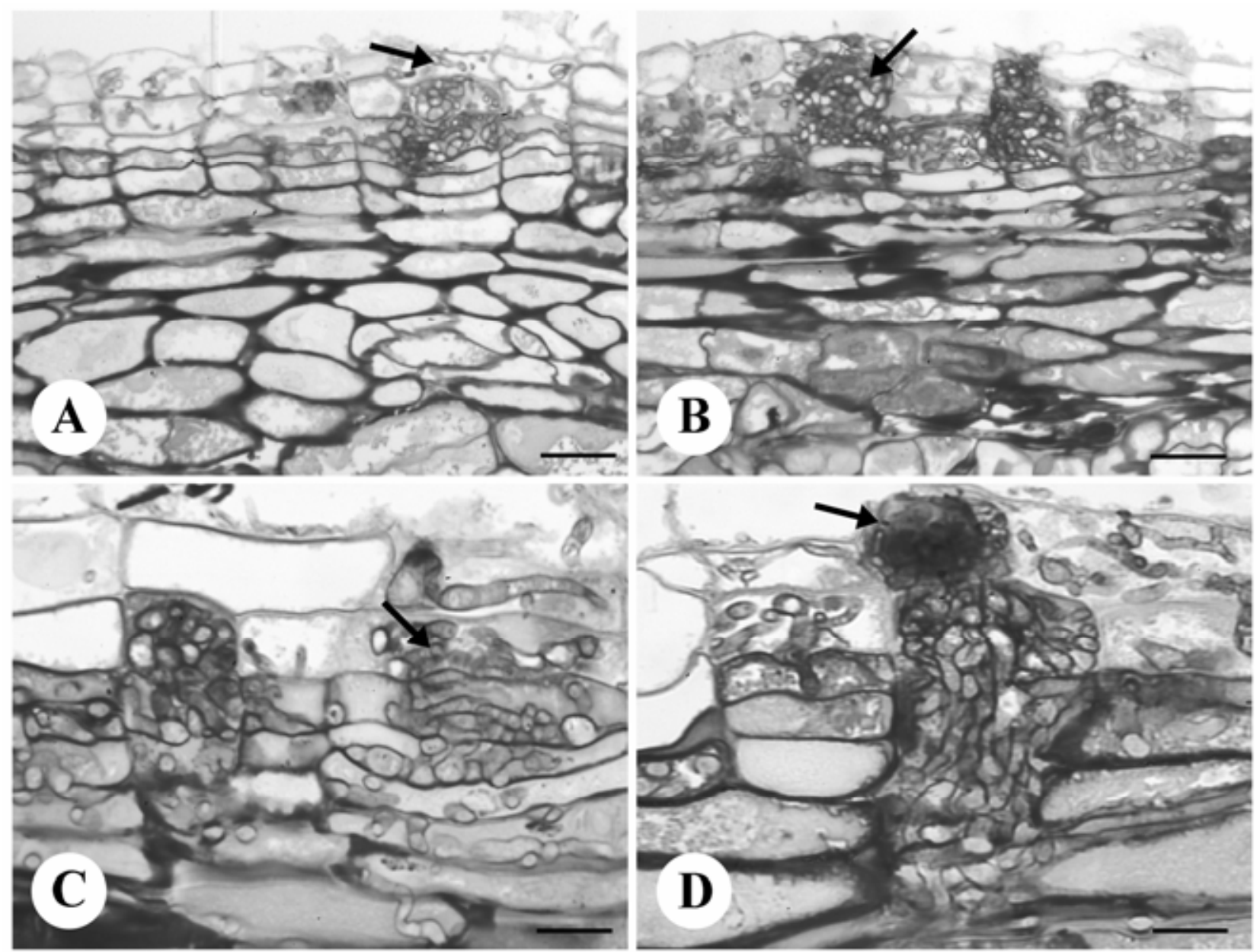

Fig. 7. The progression of Cylindrocarpon destructans mycelia into ginseng root. A, Thin section of infected root showing hyphae (arrow) penetrating through the epidermis and underlying mycelium in cortical cells; scale bar $=60 \mu \mathrm{m}$. B. Hyphal aggregation in the epidermal and cortical cells; scale bar $=60 \mu \mathrm{m}$. C, Intracellular hyphal growth; scale bar $=24 \mu \mathrm{m}$. D, Possible entry point of hyphae on the root surface and downward penetration of hyphae through 6-8 cell layers; scale bar $=24 \mu \mathrm{m}$. 
While $C$. destructans is generally considered to be a weak pathogen on many host plants (18), our study revealed that both weakly virulent and highly virulent strains are present in ginseng fields in British Columbia. This confirms the work of Seifert et al. (36) who showed that ginseng-adapted isolates from other major ginseng-growing areas of the world (Ontario, Canada, and Korea) could be very devastating because of their high virulence. However, the role of weakly virulent isolates in root rot was not discussed. In earlier studies (10) on ginseng root rot and rusty root, isolates of Ramularia (now classified as Cylindrocarpon), were also shown to differ in pathogenicity to ginseng roots as evidenced by development of lesions of different sizes and depths on artificially inoculated as well as naturally infected roots. In our study, in vitro pathogenicity tests on 4-year-old roots showed that approximately one-half of the isolates of C. destructans $(51 \%)$ were unable to initiate lesions on unwounded roots but caused lesions only following wounding. These isolates were characterized as weakly virulent. The role of these isolates in root rot development on ginseng roots under field conditions would be contingent on the presence of wounds. The wounds created in this study were minor (made by a small pin). Such wounds could readily occur during growth of ginseng roots by nematode feeding, winter freezing and spring thawing, or by soil-inhabiting insects. Slootweg (37) reported that $C$. radicicola when inoculated alone on the roots of narcissus produced no lesions, whereas the fungus inoculated together with Pratylenchus penetrans caused extensive lesions. Similar findings were obtained by Hustings and Bosher (11) who concluded that nematodes were likely to be the predisposing agents for infection of plants by $C$. radicicola. Thus, it is likely that other organisms accompanying weakly virulent C. destructans can facilitate its entrance into the ginseng root. Nematode infection of ginseng roots has been observed in the field (M. Rahman and Z. K. Punja, unpublished data) and many of these roots had accompanying Cylindrocarpon lesions. Wounding has been shown to enhance diseases caused by many other soilborne pathogens such as Cephalosporium graminearum (38), Phytophthora capsici (2), and Chalara elegans (28). Broken-off root tips and the junction of primary and lateral roots can also provide natural entry points for $C$. destructans. On roots inoculated with a mycelial suspension in vitro and in hydroponically maintained inoculated roots, lesions due to $C$. destructans developed primarily near the junction of primary and lateral roots (Fig. 1F). A histopathological study of the infection process by a highly virulent isolate revealed that direct penetration of the root epidermis as well as ramification of mycelium in the cortical cells took place. Thus, it is possible that highly virulent isolates infect

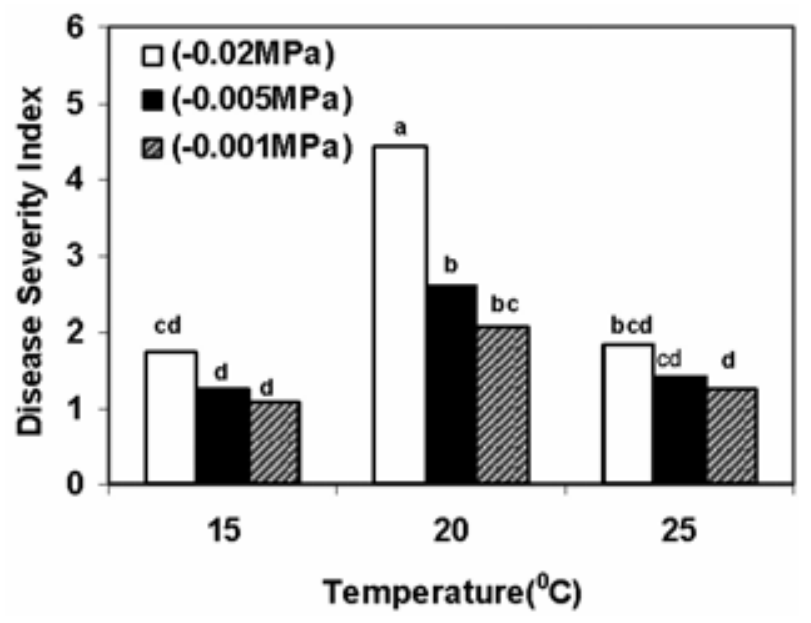

Fig. 8. Effect of soil moisture and temperature on Cylindrocarpon root rot. Bars followed by the same letter are not significantly different from each other according to Fisher's protected LSD test $(P \leq 0.05)$. the roots first and secondary colonization by weakly virulent isolates could follow. The fact that almost one-half of the isolates recovered were weakly virulent suggests that they are prevalent. Although Hildebrand (10) reported that some C. destructans isolates obtained from ginseng with rusty root symptoms were pathogenic on ginseng root, we recovered only one isolate from rusty roots and almost all of our isolates came from visibly rotted roots. We have evidence to indicate that rusty root symptoms on ginseng are likely caused by infection by Fusarium spp. and not C. destructans (30).

The results from our study revealed marked differences in pectolytic enzyme production between isolates of $C$. destructans with different virulence to ginseng roots. A higher pectinase activity level was recorded for highly virulent isolates compared with weakly virulent isolates. Lyr and Kluge (16) reported that various C. radicicola isolates differed in pathogenicity on pine, and isolates that exhibited stronger pathogenicity produced more pectolytic enzymes. Similar results were obtained by Manka (17) in studies on pectolytic activity in Fusarium sp. isolates pathogenic to corn seedlings. PPO production by $C$. destructans may be another potential contributor to lesion development on ginseng roots. The dark brown, sunken lesions caused by $C$. destructans may be the outcome of degradation of host phenolic compounds by PPO. Ginseng roots produce a range of phenolic compounds, including ginsenosides/ginseng saponins that are the principal bioactive compounds in ginseng (42). PPO production by fungi is usually induced by phenolic substances in the host plant or in artificial media and helps the pathogen to degrade cell wall constituents or to detoxify host quinones by polymerization (19). Ginseng cells colonized by $C$. destructans stained a bluish-green color with Toluidine blue $\mathrm{O}$, indicating the presence of phenolic compounds (27). Our study shows that highly virulent isolates of C. destructans (detected by in vitro root inoculation and PCR primers) produced significantly higher PPO compared with weakly virulent isolates. Thus, a combination of pectinase and PPO may be responsible for the disappearing root rot symptom due to $C$. destructans on ginseng roots.

A hydroponic method for maintaining ginseng plants was used to visualize how $\mathrm{pH}$ and wounding affected disease development. Acidic $\mathrm{pH}$ significantly enhanced disease development on wounded roots compared with neutral $\mathrm{pH}$. A number of soilborne pathogens are affected by soil $\mathrm{pH}$. Club root of crucifers was reduced by liming the soil to above $\mathrm{pH} 7.0$, and at $\mathrm{pH} 7.8$, the dis-

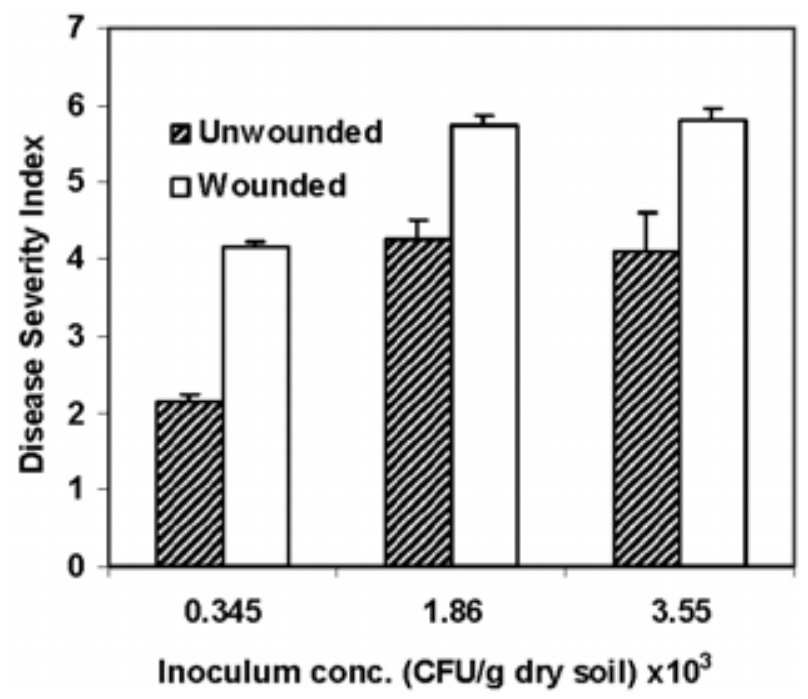

Fig. 9. Effect of inoculum concentration and wounding on Cylindrocarpon root rot development; Data from three experiments having three replicate pots for each treatment with two roots in each pot were pooled after testing the homogeneity of variance. Vertical bars represent the standard errors of means $(n=18)$. 
ease was completely inhibited (9). Murray et al. (21) reported that the percentage of infected stems due to cephalosporium stripe decreased significantly when $\mathrm{Ca}(\mathrm{OH})_{2}$ was added to increase soil $\mathrm{pH}$ from 5.1-5.3 to 6.0, and disease was significantly increased when $\mathrm{H}_{2} \mathrm{SO}_{4}$ was added to reduce soil $\mathrm{pH}$ to 4.5 . Our findings suggest that soil $\mathrm{pH}$ may influence development of root rot on ginseng caused by $C$. destructans since growth in pure culture and lesion development on roots were significantly reduced at $\mathrm{pH} 7.0$ compared with pH 5.0.

Root rot severity or tissue disintegration due to Cylindrocarpon infection was influenced by root age, and older roots had a higher number of shallow/superficial lesions while younger roots rotted completely. It is possible that root rot is more evident on older roots in the field because of inoculum buildup in gardens over time and carryover of the pathogen from second-year to fourthyear roots. A low infection frequency on 1-year-old roots could be reflective of the lower root surface area that had come into contact with soil inoculum. Deposition of pectic and other cell wall fortifying substances in older root tissues over time may maintain the integrity of roots even when diseased. In this study, although we observed low disease incidence in younger roots, the diseased roots scored higher for severity, which contributed to higher disease severity index on a cumulative scale. Since roots of different ages were not available from the same garden, we used roots from different gardens that were dug up with extreme care and followed by washing under running water to select only the healthy and blemish-free roots for the experiment. Control roots from different age groups did not show any rot lesions at the time of evaluation of the roots.

Among several variables that can influence Cylindrocarpon root infection and disease development, we investigated the effect of and interaction between two important factors, soil moisture and temperature. The highest disease severity was at $20^{\circ} \mathrm{C}$, close to the optimum temperature for growth of the pathogen $\left(18^{\circ} \mathrm{C}\right)$. All experiments on the effect of temperature on Cylindrocarpon root rot consistently showed lower disease severity at 15 and $25^{\circ} \mathrm{C}$ compared with $20^{\circ} \mathrm{C}$. Our findings also suggest that temperature plays a bigger role in cylindrocarpon root rot development compared with moisture. Moisture effect showed a very similar trend $(-0.02>-0.005>-0.001 \mathrm{MPa})$ on disease development in combination with all three temperatures tested, indicating very little interaction effects. The arid ginseng-growing regions in British Columbia would make the occurrence of high moisture levels during the season unlikely and most soils would be at or below field capacity. While high soil moisture favors development of root and seed rots, including those caused by Pythium and Phytophthora spp. (35), our findings suggest that $C$. destructans growth and infection is not enhanced by soil moisture above field capacity. Growth and competitiveness of the fungus may be reduced under these conditions. A similar study (10) with a range of temperatures and 70 and $50 \%$ of moisture-holding-capacity of soil showed no disease incidence at 26 to $28^{\circ} \mathrm{C}$. However, our study demonstrated moderate disease incidence $(\sim 50 \%)$ at $25^{\circ} \mathrm{C}$, but the disease severity was lower at this temperature compared with 15 and $20^{\circ} \mathrm{C}$.

While wounding was a prerequisite for lesion development on ginseng roots by weakly virulent isolates, wounding also enhanced disease severity for highly virulent isolates. At moderate inoculum levels $\left(1.86 \times 10^{3} \mathrm{CFU} / \mathrm{g}\right.$ of dry soil $)$, disease severity was similar to that at higher inoculum levels $\left(3.55 \times 10^{3} \mathrm{CFU} / \mathrm{g}\right.$ of dry soil) if the roots were wounded, which confirmed the results from our hydroponic study. In unwounded wheat plants, average incidence of cephalosporium stripe diseased tillers increased from 0.5 to $22 \%$ as inoculum density increased from 3.4 to $6.4 \log _{10}$ conidia/g of soil, whereas in plants whose root systems were cut immediately before infesting soil with conidia, average disease incidence increased from 16.1 to $76.7 \%$ with the same increase in inoculum density (38).
The natural inoculum levels of $C$. destructans in soil in ginseng gardens are not known because the pathogen is difficult to recover from soil by normal soil dilution procedures. Reeleder et al. (33) have described a method for extracting Cylindrocarpon DNA from multiple large soil samples that may be useful to monitor populations of the pathogen in soils, thereby permitting an assessment of the effects of different treatments in reducing soil inoculum levels. Given that thick-walled chlamydospores are produced in soil $(18,33)$ and the pathogen has a wide host range, elimination of $C$. destructans from ginseng gardens may prove to be difficult. Managing soil factors such as $\mathrm{pH}$ and minimizing wounding due to nematodes, insects, and extremes of weather may prove to be partially effective in disease management. Genetic resistance in ginseng roots to $C$. destructans has not been reported. However, recent developments in tissue culture $(29,40)$ and genetic transformation of ginseng $(5,6)$ and the expression of antifungal proteins in transgenic plants (26) could lead to the development of ginseng roots with enhanced tolerance to pathogens such as $C$. destructans in the future.

\section{ACKNOWLEDGMENTS}

The cooperation of Chai-Na-Ta Ginseng Corp. and use of their facilities, provision of plant materials, and financial support is greatly appreciated. We thank The Natural Sciences and Engineering Research Council of Canada (Discovery Grants Program), The Science Council of British Columbia, GREAT awards program, and The Associated Ginseng Growers of British Columbia for their financial assistance. We also thank E. R. Littley for advice and Nitin Verma and Raymond Yip for assistance in preparing the figures.

\section{LITERATURE CITED}

1. Al-Samarrai, T. H., and Schmid, J. 2000. A simple method for extraction of fungal genomic DNA. Lett. Appl. Microbiol. 30:53-56.

2. Adorada, D. L., Biles, C. L., Liddell, C. M., Fernandez-Pavia, S., Waugh, K. O., and Waugh, M. E. 2000. Disease development and enhanced susceptibility of wounded pepper roots to Phytophthora capsici. Plant Pathol. (Oxf) 49:719-726.

3. Booth, C. 1966. The Genus Cylindrocarpon. Mycol. Pap. No. 104. CMI, Kew, Surrey, England.

4. Buonassissi, A., and MacDonald, L. S. 1990. Ginseng diseases in British Columbia from 1987-1989. Can. Plant Dis. Surv. 70:77.

5. Chen, W. P., and Punja, Z. K. 2002. Agrobacterium-mediated transformation of American ginseng with a rice chitinase gene. Plant Cell Rep. 20:1039-1045.

6. Chen, W. P., and Punja, Z. K. 2003. Introduction and expression of a thaumatin-like protein from rice in American ginseng following Agrobacterium-mediated transformation. J. Ginseng Res. 27:17-23.

7. Dingle, J., Reid, W. W., and Solomons, G. L. 1953. The enzymatic degradation of pectin and other polysaccharides. II. Application of the cup-plate assays to the estimation of enzymes. J. Sci. Food Agric. 4: 149-155.

8. Duckworth, H., and Coleman, J. 1970. Physicochemical and kinetic properties of mushroom tyrosinase. J. Biol. Chem. 245:1613-1619.

9. Fletcher, J. T., Hims, M. J., Archer, F. C., and Brown, A. 1982. Effects of adding calcium and sodium salts to field soils on the incidence of clubroot. Ann. Appl. Biol. 100:245-251.

10. Hildebrand, A. A. 1935. Root rot of ginseng in Ontario caused by members of the genus Ramularia. Can. J. Res. 12:82-114.

11. Hustings, R. J., and Bosher, J. E. 1938. A study of the pathogenicity of the meadow nematode and the associated fungus Cylindrocarpon radicicola. Can. J. Res. 16:225-229.

12. Lee, M. W. 1977. Studies on the root rot of ginseng (VII)-pathogenic microbial population in continuous culture and first-time culture of ginseng. Korean J. Microbiol. 15:20-30.

13. Leger, R. J. S., Charnley, A. K., and Cooper, M. 1988. Production of polyphenol pigments and phenoloxidases by the entomopathogen, Metarhizium anisopliae. J. Invertebr. Pathol. 52:215-220.

14. Li, T. S. C. 1995. The effects of chemical and organic treatment on ginseng seedlings planted in old ginseng soil. Pages 201-204 in: Proc. Int. Ginseng Conf. W. G. Bailey, C. Whitehead, J. T. A. Proctor, and J. T. Kyle, eds, Vancouver, Canada.

15. Li, T. S. C., and Utkhede, R. S. 1993. Pathological and nonpathological diseases of ginseng and their control. Curr. Top. Bot. Res. 1:101-113. 
16. Lyr, H., and Kluge, E. 1968. Zusammenhange zwischen Pathogenitat, Enzym-und Toxinproduktion bei Cylindricarpon radicicola. Phytopathol. Z. 62, 220-231.

17. Manka, K. M. 1981. Cellulolytic and pectolytic activity of Fusarium isolates pathogenic to corn seedlings. Acta Microbiol. Pol. 1:25-32.

18. Matturi, S. T., and Stenton, H. 1964. Distribution and status of Cylindrocarpon species in the soil. Trans. Br. Mycol. Soc. 47:577-587.

19. Mayer, A. M., and Harel, E. 1979. Polyphenoloxidases in plants. Phytochemistry 18:193-215.

20. McMullen, C., Yee, D., Reeleder, R. D., Seifert, K., and Dobinson, K. F. 1999. Molecular diagnostics and genetic diversity of Cylindrocarpon destructans. Can. J. Plant Pathol. (Abstr.)21:203.

21. Murray, T. D., Walter, C. C., and Anderegg, J. C. 1992. Control of cephalosporium stripe of wheat by liming. Plant Dis. 76:282-286.

22. Ohh, S. H., Yu, Y. H, Kim, K. H., and Cho, D. H. 1992. Studies on control of soil-borne diseases and insects of ginseng and development of antifungal compound. Pages 121-184 in: Korea Ginseng and Tobacco Research Inst., Ginseng Cultivation Bull. Taejon, Korea.

23. Parke, J. L., and Shotwell, K. M. 1989. Diseases of cultivated ginseng. University of Wisconsin-Madison Ext. Res. Bull. 3465.

24. Proctor, J. T. A., and Bailey, W. G. 1988. Ginseng: Industry, botany and culture. Hortic. Rev. 9:188-236.

25. Punja, Z. K. 1997. Fungal pathogens of American ginseng (Panax quinquefolius L.) in British Columbia, Canada. Can. J. Plant Pathol. 19:301306.

26. Punja, Z. K. 2001. Genetic engineering of plants to enhance resistance to fungal pathogens-A review of progress and future prospects. Can. J. Plant Pathol. 23:216-235.

27. Punja, Z. K. 2004. Virulence of Chalara elegans on bean leaves and host tissue responses to infection. Can. J. Plant Pathol. 26:52-62.

28. Punja, Z. K., Chittaranjan, S., and Gaye, M. M. 1992. Development of black root rot caused by Chalara elegans on fresh market carrots. Can. J. Plant Pathol. 14:299-309.

29. Punja, Z. K., Feeney, M., Schluter, T., and Tautorus, T. 2004. Multiplication and germination of somatic embryos of American ginseng derived from suspension cultures and biochemical and molecular analyses of plantlets. In Vitro Cell. Dev. Biol. Plant 40:329-338.

30. Punja, Z. K., Wan, A. M., and Rahman, M. 2005. Role of Fusarium species in rusty root development on ginseng roots. Phytopathology 95 (Abstr.). In press.

31. Rahman, M., and Punja, Z. K. 2004. Epidemiology of Cylindrocarpon root rot and rust spot on American ginseng (Panax quinquefolius). Can. J. Plant Pathol. (Abstr.)26:124.

32. Reeleder, R. D., and Brammal, R. A. 1994. Pathogenicity of Pythium species, Cylindrocarpon destructans, and Rhizoctonia solani to ginseng seedlings in Ontario. Can. J. Plant Pathol. 16:311-316.
33. Reeleder, R. D., Capell, B. B., Tomlinson, L. D., and Hickey, W. J. 2003. The extraction of fungal DNA from multiple large soil samples. Can. J. Plant Pathol. 25:182-191.

34. Reeleder, R. D., Roy, R., and Capell, B. B. 1999. Seed and root rots of ginseng (Panax quinquefolius) caused by Cylindrocarpon destructans and Fusarium spp. J. Ginseng Res. 26:151-158.

35. Schmitthener, A. F. 1970. Significance of populations of Pythium and Phytophthora in soil. Pages 25-27 in: Proc. Second Int. Symp. On Factors Determining the Behavior of Plant Pathogens in Soil. T. A. Toussoun, R. V. Vega, P. E. Nelson, eds, London, UK.

36. Seifert, K. A., McMullen, C. R., Yee, D., Reeleder, R. D., and Dobinson, K. F. 2003. Molecular differentiation and detection of ginseng-adapted isolates of the root rot fungus Cylindrocarpon destructans. Phytopathology 93:1533-1542.

37. Slootweg, A. T. G. 1956. Root rot of bulbs caused by Pratylenchus and Haplolaimaus spp. Nematologia 1:192-201.

38. Specht, L. P., and Murray, T. D. 1990. Effects of root wounding and inoculum density on Cepahalosporium stripe in winter wheat. Phytopathology 80:1108-1114.

39. Sutherland, J. R., Shrimpton, G. M., and Surrock, R. N. 1989. Diseases and insects in British Columbia forest seedling nurseries. FRDA Report No. 065. Forestry Canada and B.C. Ministry of Forests, Victoria.

40. Tirajoh, A., Kyung, T., and Punja, Z. K. 1998. Somatic embryogenesis and plantlet regeneration in American ginseng (Panax quinquefolius L.). In Vitro Cell. Dev. Biol. Plant 34:203-211.

41. Unestam, T., Beyer-Ericson, L., and Strand, M. 1989. Involvement of Cylindrocarpon destructans in root death of Pinus sylvestris seedlings: Pathogenic behavior and predisposing factors. Scand. J. For. Res. 4:521-535.

42. Wu, J. Y., and Zhong, J. J. 1999. Production of ginseng and its bioactive components in plant cell culture: Current technological and applied aspects. J. Biotechnol. 68:89-99.

43. Yu, Y. H., and Ohh, S. H. 1993. Research on ginseng diseases in Korea. Korean J. Ginseng Sci. 17:61-68.

44. Yu, Y. H., and Ohh, S. H. 1995. Problems and present status of research on ginseng diseases in Korea. Pages 120-130 in: Proc. Int. Ginseng Conf. W. G. Bailey, C. Whitehead, J. T. A. Proctor, and J. T. Kyle, eds. Vancouver, Canada.

45. Ziezold, M., Hall, R., Reeleder, R. D., and Proctor, J. T. A. 1998. Toxicity of fungicides in vitro to Cylindrocarpon destructans. J. Ginseng Res. 22:223-228

46. Ziezold, M., Hall, R., Reeleder, R. D., and Proctor, J. T. A. 1998. Seedborne fungi and fungicide seed treatment of ginseng. J. Ginseng Res. 22:229-236.

47. Ziezold, M., Reeleder, R. D., Hall, R., and Proctor, J. T. A. 1998. Effect of drenching soil with benomyl, propiconazole, and fluazinam on incidence of disappearing root rot of ginseng. J. Ginseng Res. 22:237-243. 